\title{
MODEL PENDIDIKAN KARAKTER UNTUK MEMBANGUN POTENSI HARMONI SOSIAL ANAK USIA DINI DI YOGYAKARTA
}

\author{
Harun \\ Universitas Negeri Yogyakarta \\ Email: harun@uny.ac.id
}

\begin{abstract}
Abstrak
Penelitian ini bertujuan untuk menemukan potensi harmoni sosial anak usia dini dalam pembelajaran di TK kota yogyakarta, dalam rangka membangun dan memantau perkembangan kemampuan harmoni sosial, harmoni budaya anak, serta memiliki kematangan sosial-emosional yang mandiri dan berbudaya. Penelitian ini dirancang untuk dilakukan dalam tiga tahun. Pada tahun pertama peneliti mengadopsi model research, development, and diffussion, yang meliputi penelitian pendahuluan, studi hasil penelitian, analisis kurikulum, dan penyusunan prototype model. Riset pendahuluan untuk memperoleh informasi model pendidikan karakter dalam membangun potensi harmoni sosial anak usia dini. Analisis yang dilakukan pada tahan ini untuk mengetahui dan memetakan standar kompetensi dan indikator pencapaian dalam rangka untuk menjaring need assessment sebagai dasar merancang prototype model pendidikan untuk membangun harmoni sosial anak usia dini di Yogyakarta. Hasil penelitian pada tahun pertama ini menunjukkan bahwa harmoni sosial anak usia dini dibangun atas dasar kejujuran yang ditampilkan anak, ungkapan isi hati, tidak saling menyakiti, tolong menolong, tidak saling berebut untuk berbicara, tidak saling menyakiti antar teman, serta terbentuknya budaya antri dalam berbagai kegiatan.
\end{abstract}

Kata kunci: harmoni sosial, anak usia dini

\section{CHARACTER EDUCATION MODEL TO BUILD THE POTENCY OF SOCIAL HARMONY OF EARLY CHILDHOOD IN YOGYAKARTA}

\begin{abstract}
This research aims to find potential social harmony early childhood learning in kindergarten in the city of yogyakarta, in order to establish and monitor the development of the ability of social harmony, the harmony of the culture of children, as well as having the maturity of social-emotional and cultured. This research was designed to be done in three years. In the first year of the researchers adopted a model of research, development, and diffussion, which include research studies, preliminary research results, an analysis of the curriculum, and the preparation of the prototype model. Preliminary research to obtain information model of character education in building social harmony potential early childhood. The analysis conducted on these resistant to know and map the standard of competency and indicators of achievement in order to capture the need assessment as the basis for designing prototype model of education to build social harmony in early childhood Yogyakarta. Results of the study in the first year shows that early childhood social harmony is built on the basis of honesty displayed child, an expression of heart's content, not hurt each other, please help, not mutually scramble for talking, not mutually hurt between friends, as well as the formation of the culture of lining up in a variety of activities.
\end{abstract}

Keywords: social harmony, early childhood 


\section{PENDAHULUAN}

Manusia dalam menjalani hidupnya terutama ketika berkomunikasi dan berinter-aksi dengan manusia lain serta lingkungannya didominasi oleh kemampuan berbahasa. Dengan bahasa yang digunakan akan membantu mereka dalam berpikir dan berbuat bahkan Morrison (1988:194) mengatakan bahwa berkomunikasi itu sangat ditentukan oleh tingkat kemampuan berbahasa dan budaya seseorang. Sebab, bahasa memiliki dua fungsi yaitu sebagai public speech dan sebagai private speech. Tingkat kemampuan berbahasa seseorang, sangat dipengaruhi oleh seringnya kata-kata diucapkan kepada anak sejak dini secara berulang-ulang (Oberlander, 2005:6), yang selalu didengar di lingkungannya, sebagai dasar peletakkan budaya bagi anak. Jadi, berkomunikasi dengan menggunakan bahasa pada anak usia dini merupakan usaha strategis yang harus dilakukan terus dalam pendidikan anak usia dini (Molfese, et al., 2006:297), sebagai langkah awal dalam membangun potensi harmoni sosial budaya bagi anak. Sebab kemampuan bahasa dapat berfungsi secara optimal, manakala anak usia dini terbiasa berkomunikasi dengan menggunakan bahasa yang mereka dengar secara berulang-ulang (Hill-Clark, 2005:46), dalam interaksi sosial budaya mereka.

Seorang anak akan berinteraksi dengan anak lainnya jika ia memiliki kemampuan sosial, budaya dan bahasa yang ada di dalam dirinya. Anak akan mulai bermain bersama anak bermain, merupakan refleksi dan pengaruh dari perkembangan cognitif dan motor kasar maupun motor halus sebagai wilayah sosial dan emosional anak, Vygotsky (Crain, 2005:218). Bangunlah interaksi dengan mereka agar potensi harmoni sosial anak dapat tumbuh dan berkembang secara baik dan optimal. Pada rentang usia TK, mereka sudah dapat berinteraksi dengan anak lainnya dalam kelompok bermain, dan dengan orang lain di sekitarnya, seperti mengekplorasi lingkungan, membentuk kelompok sosial dan membuat ikatan kelompok sebaya (Berk, 1989:416), memilih dan menggabungkan pengalaman budaya untuk menunjukkan harmoni sosial (Berk, 1989:229). Anak juga telah dapat berinteraksi dengan anggota keluarganya dan dengan gurunya, teman-temannya, dan dengan saudaranya secara baik (Papalia \& Olds, 2001:310). Interaksi sosial tersebut merupakan rentang pengalaman baru bagi anak usia dini dalam situasi sosial yang mereka hadapi (Arthur et. al, 1998:81). Di sekitar mereka ada yang bermain, di situlah mereka bergabung bermain bersama. Mereka bernegosiasi dan berinteraksi secara cepat (Gray, 2000:300), di sana pulalah mereka belajar berteman, belajar memecahkan masalah bersama (Papalia \& Olds, 2001:313), di sanalah merupakan pusat harmoni sosial terbentuk antar anak.

Penelitian ini diilhami oleh kondisi sosial empirik yang memprihatinkan selama ini, yang ditunjukkan melalui berita media cetak maupun elektronika bahwa seakan-akan sudah tiada lagi perasaan aspek budaya sebagai harmoni sosial yang tertanam di dalam hati sanubari setiap anak bangsa. Misalnya: orang tidak lagi merasa iba dan kasihan terhadap orang lain sehingga tega untuk membunuh dan memutilasinya; orang sudah mulai tidak lagi merasa bersalah jika menabrak seseorang kemudian ditinggal lari; orang berbuat seenaknya melanggar ramburambu lalu-lintas tanpa merasa salah; dan orang sudah sangat mudah melakukan penganiayaan meskipun penyebabnya sangat sepele. Contoh-contoh tersebut hanyalah bagian kecil dari tumpukan gunung es permasalahan sosial dan harmoni budaya yang semestinya tersemai di dalam diri setiap individu. Adakah hal tersebut merupakan akibat dari tiadanya pendidikan yang membentuk dan membangun harmoni sosial-budaya yang dilakukan sejak anak usia dini?

Pada anak usia dini (TK) terdapat perubahan sosial sebagai awal tumbuhnya onlooker play terhadap parallel play. Hal ini merupakan ciri pada umumnya anak normal, dan mereka sudah mampu belajar mensosialisasi diri dalam lingkungan 
budaya khusus. Pada tahap perkembangan ini mereka juga telah mampu memaknai suatu kejadian sebagai struktur dan proses sosial-emosional seperti konsep diri, standard, dan tujuan pembentukan nilai. Hal tersebut ditandai dengan adanya rencana, sebagai bagian dari tindakan dalam situasi sosial tertentu (Martinko \& McCormick, 2004:2). Setting sosial ini oleh Bandura (Crain, 2005:197) dikatakan sebagai proses sosial kognitif. Proses perkembangan sosial akan menjadi suatu tampilan budaya, seperti dikatakan (Crain, 2005; Papalia \& Olds, 2001) manakala terjadi proses perhatian, proses ingatan, proses reproduksi gerak, proses pembentukan dan penguatan motivasi, dan inisiatif pada diri anak itu sendiri. Dalam hal ini Papalia \& Olds (1986:232) menambahkan adanya Common activity (doing things together), affection (liking, caring for), support (sharing, helping) and to a lasser degree, propinquity (living nearby or going to the same school), have more positive attitudes toward school, sebagai awal proses perkembangan harmoni sosial budaya anak.

Perkembangan sosial-emosional sebagai dasar pembentukan harmoni sosial-budaya anak TK harus memperhatikan proses bermain anak yang dipengaruhi oleh beberapa aspek perkembangan kognitif, motorik, sebagai wilayah sosial budaya dan emosional anak (Rasyid, 2008:45). Dengan demikian, elemen sosial dan budaya dalam permainan anak harus didesain secara serius sehingga anak TK dapat bergerak secara leluasa sesuai dengan jenis dan perbedaan permainan yang mereka sukai. Setidaknya, suatu jenis permainan dapat mencerminkan elemen sosial dan budaya dalam permainan itu, seperti kesempatan bekerjasama, berasosiasi, dan berbagi, serta berempati. Itulah yang disebut Papalia \& Olds (1986:234) sebagai social play (paralel, associative, and cooperative), yaitu potensi harmoni sosial dan budaya yang harus dipupuk terus sejak usia dini. Proses pembentukan manusia seutuhnya mengandung makna bahwa manusia itu tidak hanya memiliki jiwa dan raga yang bisa dikembangkan lewat pendidikan, melainkan ia memiliki fithrah/budaya yang juga harus dikembangkan. Mengabaikan pengembangan fithrah/budaya dalam proses pendidikan mengakibatkan rendahnya moral yang tercemin dalam prilaku emosional dan impulsif (Depdiknas, 2000:2006). Prilaku emosional dan impulsif itu merupakan indikasi adanya aspek-aspek pokok yang terlupakan dalam proses pendidikan yang selama ini berlangsung. Aspek itu ialah,fithrah/budaya sebagai ciri khusus manusia berperadaban.

Fithrah, yang merupakan potensi dasar manusia sebagai makhluk yang bermoral, berakhlak, dan makhluk yang sebaik-baiknya ciptaan (QS. At-Thin:4). Akhlak dan moral merupakan naluri manusia ke arah kebaikan yang bersumber dari ajaran agama (Madjid, 1995:176), cenderung untuk berbuat baik (Purba, 2007), yang bermuara kepada Ibrahim (Abrahamic Religions). Konsep Abrahamic Religions ini meletakkan bahwa manusia itu dilahirkan dalam keadaan kesucian, yang terkenal dengan instilah fithrah atau potensi dasar. Konsep fithrah sebagai sifat dasar kesucian manusia ini, harus dinyatakan dalam sikapsikap yang suci dan baik kepada sesama manusia, yang dikondisikan berkembang atau diberdayakan (Purba, 2007). Hal ini merupakan bukti bahwa manusia itu sebagai makhluk hanif, yang memiliki dorongan naluriyah ke arah kebaikan dan kebenaran. Pusat dorongan hanif itu menurut Madjid (1995:179) terdapat dalam diri manusia yang paling dalam dan paling murni, yang disebut hati atau nurani sebagai manusia berbudaya.

Kesucian atau fithrah/budaya yang dimiliki manusia, menurut Mendiknas (2005:88) dapat dikelompokkan menjadi empat jenis: ftihrah/budaya pikir, fithrah/budaya hati dan jiwa, fithrah/budaya rasa, dan fithrah/budaya raga. Keempat fithrah/budaya yang dimiliki manusia itu, jika dilihat dari sisi substansi pengembangan manusia adalah 
merupakan potensi yang dapat ditumbuhkembangkan semaksimal mungkin sampai pada tahap yang optimal lewat pendidikan dan latihan. Pengembangan potensi yang optimal itu memungkinkan manusia menjadi manusia yang cerdas, mandiri, berbudi, berbudaya, dan berakhlak mulia (Purba, 2007) sekaligus mudah beradaptasi dalam keragaman budaya sebagi bentuk harmoni sosial. Potensi pikir manusia merupakan anugrah Allah yang sangat tinggi, sekaligus sebagai pembeda dengan makhluk lainnya, yang sanggup memahami dan menganalisis sesuatu (Quraish, 2000:292), mampu berpikir dengan menggunakan simbol (Papalia \& Olds, 1986:234), dalam keragaman sebagai harmoni sosial. Potensi pikir yang bertugas memikirkan sesuatu di luar dirinya memerlukan pertimbangan hati dan jiwa secara matang, untuk membuat keputusan sebagai formulasi moral (Papalia \& Olds, 1986:250), sehingga terbentuk harmoni budaya.

Manusia yang memikirkan suatu keputusan perbuatan yang dilandasi oleh pertim-bangan hati dan jiwa yang jernih, ia masih memerlukan suatu kedalaman akibat keputusan perbuatan itu, ialah rasa. Rasa berfungsi sebagai sesuatu yang sangat menentukan baik buruknya akibat dari perbuatan untuk dilakukan atau tidak dilakukan. Rasa merupakan bagian aspek ruhaniyah yang sangat dalam dan suci yang bersumber pada pikiran, hati dan jiwa manusia dalam berbagai situasi, Papalia \& Olds (1986:251). Potensi rasa, hati, jiwa, serta potensi pikir yang dimiliki manusia akan berfungsi bersama ketika manusia itu berpikir dan mempertimbangkan suatu keputusan untuk berbuat sesuatu. Ketiga potensi ini akan berdampak pada raga yang bertugas melaksanakan hasil olah pikir yang dilandasi oleh hati dan jiwa yang jernih, serta rasa yang dalam untuk tampil dalam performance dan perbuatan yang dilakukan, serta mengandung nilai moral yang tinggi sebagai implikasi harmoni sosial. Oleh karenanya, potensi rasa tersebut harus menjadi arah dan substansi pendidikan yang ditumbuhkembangkan sejak anak usia dini, sehingga kelak menjadi manusia yang memiliki rasa yang dalam dan memiliki moral behavior. Muaranya adalah manusia yang berbudi, berakhlak mulia, serta manusia yang memiliki harmoni budaya dan bermoral tinggi. Jadi, pendidikan itu harus mengarah pada pengembangan potensi ragawi sesuai tahapannya (Piaget, 1974:78), sebagai upaya pembentukan karakter bangsa untuk menentukan eksistensi bangsa di masa depan. Pembentukan karakter bangsa haruslah dimulai dari diri anak sejak masa tumbuh kembang di usia prasekolah sebagai investasi masa depan (Jalal, 2004:43). Melalui model pendidikan untuk membangun harmoni sosial-budaya bangsa Indonesia. Dengan demikian, yang menjadi masalah dalam penelitian ini adalah bagaimanakah pelaksanaan model pendidikan karakter anak usia dini untuk membangun harmoni sosial di Yogyakarta.

\section{METODE \\ Desain penelitian}

Penelitian ini merupakan penelitian pengembangan dengan mengadopsi model yang dikembangkan oleh Hopkins \& Clark yaitu model Research Development and Diffussion (Havelock, 1976:34). Pada tahap research ini, kegiatan yang dilakukan meliputi penelitian pendahuluan, studi hasil-hasil penelitian, analisis kurikulum, dan penyusunan proptotype model sehingga untuk mencapai tujuan tersebut, peneliti mengadopsi model research, development, and diffussion. Penelitian tahap ini meliputi penelitian pendahuluan, studi hasil-hasil penelitian, analisis kurikulum, dan penyusunan proptoype model. Penelitian pendahuluan dimaksudkan untuk memperoleh informasi model pendidikan untuk menumbuhkan potensi harmoni sosial yang dilakukan selama ini dilakukan di TK. Studi hasil penelitian untuk mengetahui apa yang telah dilakukan para pakar dalam kaitan dengan topik yang diteliti. Analisis kurikulum untuk mengetahui dan memetakan standar 
kompetensi dan indikator pencapaian. Tahapan tersebut dimaksudkan untuk menjaring need assessment sebagai dasar merancang prototype model pendidikan untuk membangun harmoni sosial anak usia dini.

\section{Teknik Pengumpulan Data}

Pada penelitian pendahuluan, data dikumpulkan dengan metode angket, wawancara, demonstrasi, dan observasi langsung. Pedoman wawancara dan observasi dikembangkan peneliti sebelum terjun ke lapangan, sebagai panduan dalam mengumpulkan informasi yang diperlukan.

\section{Subyek Penelitian}

Pada tahap pertama ini, yaitu pada tahap research subyek penelitian adalah guru TK di Propinsi Daerah Istimewa Yogyakarta. Karena keterbatasan peneliti, sarana, waktu dan biaya, maka diambil sampel dari populasi. Untuk menjamin sampel yang representatif, teknik pengambilan sampel yang digunakan adalah teknik proportional stratified random sampling (Krathwohl, 1998:46) TK di Propinsi Daerah Istimewa Yogyakarta terbagi ke dalam dua tipe TK, yaitu tipe A (TK Negeri dan pembina), tipe B (TK Swasta). Setiap TK dipilih secara random berdasarkan proporsi masingmasing. Guru TK yang terpilih pada sekolah tersebut menjadi subjek penelitian pendahuluan.

\section{Analisis Data}

Analisis data hasil penelitian pendahuluan dilakukan dengan menggunakan pendekatan deskriptif kualitatif disertai dengan narasi yang sesuai dengan kepentingan penelitian. Analisis data pada saat pengembangan model dilakukan untuk melihat kesesuaian model yang dibangun berdasarkan konstruk teori dengan data empirik. Untuk keperluan tersebut, digunakan kriteria efektifitas model yang dikembangkan berdasarkan kajian teoritis yang mendalam. Kesesuaian antara model dengan data empirik disesuaikan dengan criteria yang dikembangkan dalam praktik pelaksanaan di lapangan. Jika terdapat kesesuaian antara kriteria dengan praktik pelaksanaan di lapangan, maka model yang dikembangkan fit (terdapat kesesuaian antara konsep teoritis dengan data empirik). Tetapi, jika belum fit, maka penelitian terus dilakukan dengan melakukan perbaikan berdasarkan temuan di lapangan, sampai menemukan kesesuaian (Nitko \& Brookhart, 2007:231).

\section{HASIL DAN PEMBAHASAN Hasil}

Temuan hasil penelitian lapangan yang berkaitan dengan pendidikan karakter anak usia dini dapat dideskripsikan jujur, ungkapan isi hati, tidak saling menyakiti, tolong menolong, mengembalikan barang pada tempatnya, bergantian berbicara, berpendapat, antri, saling menghargai, berbicara baik dan sopan, mendengarkan orang lain berbicara, dan berprilaku modeling. Adapun deskripsi secara lengkap adalah sebagai berikut:

Sifat jujur. Jujur dapat berupa perbuatan, ucapan, dan tindakan yang tampak dalam tampilan kehidupan seharihari. Jujur identik dengan dapat dipercaya dalam berbagai perbuatan, ucapan, tindakan dalam hidup dan kehidupan sehari-hari. Hidup jujur tidak bisa terbentuk dalam sekejap waktu, melainkan memerlukan masa yang cukup panjang. Sejak dia sebagai seorang anak, sudah harus mengenal dan tahu, diperkenalkan dan melakukan perbuatan jujur tersebut. Perbuatan yang dilakukan dengan sebenarbenarnya oleh anak, dia harus menyatakan bahwa perbuatan itu adalah murni perbuatannya, atau meniru perbuatan orang lain, atau disuruh melakukan suatu perbuatan oleh orang lain.

Ungkapan anak tersebut tidak mungkin muncul manakala anak belum pernah melakukan perbuatan tersebut. Oleh karenanya, menciptakan suasana lingkungan yang bernuansa kejujuran bagi anak usia dini merupakan bentuk usaha yang perlu dikondisikan dan terus 
dilakukan. Anak usia dini yang sedang berada pada masa emas sangat memungkinkan untuk dibentuk sikap dan perbuatan yang serta kelakuan yang mengandung cerminan sifat jujur. Dengan demikian jujur dan kejujuran bukanlah sesuatu yang muncul secara tiba-tiba, melainkan memerlukan waktu dan pembiasaan yang terus menerus. Pada muaranya kelak, sifat jujur tersebut akan terbentuk dan terakumulasi dalam berbagai sikap dan perbuatan yang jujur pula.

Orang yang bersifat jujur tidak akan pernah menyembunyikan sesuatu apapun. Dia akan mengungkapkan apa adanya sesuatu yang dia alami dan dia lakukan dengan apa adanya tanpa ditambah dan dikurangi. Sesorang akan melakukan pengakuan dengan apa adanya tidak bisa muncul secara dadakan dan tiba-tiba. Ia mesti sudah harus terbiasa mengungkapkan apa adanya yang dia lakukan itu. Orang yang tidak terbiasa tidak akan bisa untuk melakukan dan mengungkapkan pengakuan tersebut secara apa adanya. Oleh karena itu, anak usia dini di TK ABA sudah dibiasakan untuk berbuat jujur, baik dalam ucapan, perbuatan, dan pengakuan apa adanya. Pembiasaan berbuat jujur tersebut baru bisa muncul dalam bentuk sikap dan perbuatan anak manakala sudah terbiasa dilakukan minimal dalam kurun waktu selama satu bulan.

Mengungkapkan isi hati. Isi hati seseorang belum dapat diketahui seperti apa jenis dan ujudnya sebelum diekspresikan dalam bentuk perbuatan. Isi hati merupakan wadah di mana seseorang akan mengekspresikan sesuatu dalam bentuk perbuatan nyata yang dapat dilihat, dinilai dan dikomentari atau ditanggapi oleh orang lain. Isi hati yang memunculkan suatu perbuatan yang baik dan tidak menyinggung perasaan orang lain, merupakan ungkapan isi hati yang didasari oleh karakter istimewa dan terpuji. Ungkapan isi hati yang seperti inilah yang harus senantiasa ditumbuhkan dan ditanamkan sejak dini terhadap anak usia dini.
Anak usia dini sebaiknya harus dibiasakan untuk mengungkapkan isi hati secara benar dan jujur. Ungkapan isi hati ini harus dibiasakan dalam kehidupan sehari-hari di sekolah maupun ketika di rumah dibawah panduan orang tua: Ibu dan bapak sebagai pemandu utama. Membiasakan ungkapan isi hati secara jujur dan terbuka, akan menjadikan anak usia dini kelak di kemudia hari setelah ia dewasa berkelakuan baik dan berakhlak mulia. Sifat tersebut tidak bisa dibuat-buat, tidak bisa dipaksa-paksa, melain-kan harus dibiasakan oleh orang terdekatnya (orangtua/guru) dalam bertindak dan berbuat pada kehidupan sehari-hari di rumah maupun di sekolah. Mengungkapkan isi hati secara jujur dan benar memerlukan pembiasaan, bimbingan, serta memerlukan kesungguhan. Orang yang bisa membantu membiasakan, membimbing dalam tradisi pembiasaan mengungkapkan isi hati secara jujur dan benar adalah orang-orang yang paling dekat dengan anak. Orang yang paling dekat itu ialah, Ibu, bapak, dan guru mereka.

Tidak saling menyakiti. Suatu perbuatan yang dilakukan dan diucakan yang tidak mengarah pada orang lain dan atau siapa saja, mestinya tidak menimbulkan rasa sakit baik lahir maupun batin. Seseorang yang akan mengungkap perasaannya atau isi hatinya, mesti harus membuat pertimbangan yang matang, apakah ungkapan atau ucapannya itu tidak mengarah pada lahirnya rasa sakit atau rasa tidak senang orang yang mendengan ucapat tersebut. Jika seseorang sudah terbiasa dengan menghindari ucapan yang mengakibatkan orang yang mendengarnya merasa sakit atau gerah dengan ucapan itu, maka orang tersebut telah terbentuk tabiat dan perbuatannya itu sebagai kelakuan dan tabiat yang baik. Orang yang berkelakuan dan bertabiat baik, dia akan selalu menghindar dari ucapan dan perbuatan yang tidak mengenakkan orang lain. Meskipun orang lain itu telah berbuat salah atau tidak mengenakkan dirinya. 
Memang perbuatan dan ucapan yang tidak menyakiti orang lain itu sungguh sangat berat. Akan tetapi jika dibiasakan sejak anak usia dini untuk tidak melakukan perbuatan dan ungkapan yang dapat menyakiti orang lain, maka lama kelamaan anak telah terbiasa tersebut akan berusaha untuk tidak menyakiti, menyinggung, dan menggangu orang lain. Perlu disadari bersama bahwa membentuk pribadi yang berkarakter dengan tidak saling menyakiti diantara taman sesama permainan pada tahap anak usia dini, bukanlah usaha yang mudah sebagaimana membalikkan telapak tangan. Melainkan memerlukan waktu, tenaga, peluang, kesempatan yang memang harus diatur dan diusahakan sedemikian rupa agar usaha tersebut bisa terwujud dan dilakukan dilingkungan sekolah dan rumah dengan bimbingan guru dan orangtua.

Tolong menolong. Ungkapan sebuah kata tolong menolong itu begitu mudah meluncur dari mulut siapa saja. Namun dalam realita, kebiasaan memberi pertolongan kepada orang lain yang memerlukan pertolongan, ternyata amat sulit dan berat. Misalnya saja menolong orang yang memerlukan biaya sekolah anaknya. Padahal jika orang yang memerlukan pertolongan biaya tersebut dapat ditolong oleh sesorang, maka orang yang ditolong dan orang yang menolong, kedua-duanya akan memperoleh penghargaan dari Alloh dan orang mendapat pertolongan itu. Namun ternyata sangat berat untuk memberikan pertolongan kepada orang yang memerlukan pertolongan itu. Perbuatan dan sikap tolong menolong tidak dapat dibentuk seketika dalam sekejap waktu, melainkan relative memerlukan waktu yang panjang. Hal tersebut memerlukan latihan pembiasaan untuk menolong, akan membawa anak untuk menolong anak lain di tempat panti asuhan misalnya, membiasakan anak untuk melakukan pertolongan secara riil dan empirik di tempat-tempat panti sosial dan kemanusiaan.
Perlu disadari bersama bahwa pembentukan sikap dan perbuatan untuk menolong orang lain yang memerlukan pertolongan, memang memerlukan waktu yang relative panjang dan harus dawali dengan pembiasaan-pembiasaan riil dan pasti. Pembiasaan riil dapat dilakukan secara terus menerus dengan melibatkan anak usia dini secara langsung dan empirik, sehingga dipastikan dapat terbentuk pula pribadi dan jiwa yang dapat tumbuh dan berkembang serta bersemayam dalam hari sanubari anak usia dini. Usaha ini memang sangat berat, akan tetapi lembaga pendidikan taman kanak-kanak dan usia dini harus dapat memulai dan melakukannya sejak sekarang.

Mengembalikan barang pada tempatnya. Suatu perbuatan yang memerlukan pembiasaan sejak anak usia dini adalah mengembalikan barang pada tempatnya (tempat penyimpanan) sesuai dengan posisi semula. Memang sungguh sangat berat untuk meletakkan pembiasaan ini, sebab pembiasaan ini merupakan pembentukan prilaku awal yang akan mewarnai kehidupan yang bersangkutan di kemudian hari. Prilaku tersebut jika dilihat secara sepintas, sepertinya tidak memiliki dampak apapun bagi seorang anak. Namun, jika ditelaah secara mendalam tentang pembentukan prilaku seseorang anak usia dini, maka prilaku dan perbuatan mengembalikan barang pada tempatnya (tempat semula barang diambil) sungguh memiliki makna yang sangat dalam dan jauh ke depan sebagai prediksi prilaku yang mendarah-daging bagi seseorang. Misalkan saja sebagai contoh, jika kita tidak terbiasa meletakkan barang pada tempat semula yang sudah digunakan, kita sendiri akan kebingungan, manakala kita akan menggunakan kembali barang tersebut.

Anak usai dini merupakan anak usia emas, yang pada usia tersebut akan sangat mudah untuk membentuk dan meletakkan segala bentuk prilaku dan perbuatan, baik itu perbuatan baik maupun perbuatan yang tidak baik, semuanya akan tersimpan dalam memory otak anak sebagai suatu 
informasi. Sewaktu-waktu informasi tersebut dapat direcolling kembali muncul dalam perbuatan baik, maupun perbuatan yang tidak baik. Agar anak usia dini dapat memiliki simpanan perbuatan di dalam storage information yang bernilai baik dan positif, maka mestinya pendidik dan orangtua harus membiasakan terbentuknya prilaku positif, misalnya berupa pengembalian barang yang sudah dipakai pada tempat semula.

Bergantian berbicara. Berbicara memang sesuatu yang sangat penting, kerana berbicara merupakan pengungkapan isi hati seseorang secara verbal. Persoalannya adalah apakah hal yang dibicarakan itu merupakan hal yang penting atau hal yang sia-sia. Apakah peluang berbicara itu memiliki hak yang sama, atau hanya didominasi oleh seseorang saja. Apakah sesuatu yang dibicarakan itu memiliki nilai manfaat bagi yang membicarakannya maupun bagi yang mendengarnya. Pertanyaan-pertanyaan tersebut menjadi sangat penting dalam kaitannya dengan pembentukan prilaku bergantian berbicara. Anak usia dini di TK sudah dibiasakan untuk berbicara secara bergantian, sehingga setiap anak dalam suatu kasus pengungkapan pengalaman dan isi hati mereka memiliki peluang dan hak yang sama untuk berbicara. Dan, tatkala seorang anak sedang berbicara, maka anak yang lain mendengarkan dan memerhatikan terhadap apa yang sedang dibicarakan oleh anak tersebut.

Kebiasaan berbicara secara bergantian mestinya sudah harus dibentuk sejak anak usia dini, baik itu dalam lingkungan keluarga tatkala sedang berbincang-bincang santai, maupun dalam lingkungan sekolah ketika anak sedang dilatih untuk mengemukakan pendapat. Di TK ABA Yogyakarta, pembentukan prilaku berbicara secara bergantian merupakan kegiatan yang selalu dilakukan, baik pada proses pembelajaran maupun dalam kegiatan bermain bebas di ruangan maupun di luar ruangan. Kegiatan berupa aktivitas bergantian berbicara ini menjadi program rutin di sekolah, bahkan latihan diskusi dan mengemukakan pendapat serta isi hati mereka senantiasa diberikan kesempatan dan keleluasaan untuk berbicara secara bergantian.

Memberi kesempatan pada teman untuk berpendapat. Perbuatan mulia lainnya adalah memberi kesempatan kepada teman untuk berpendapat dan mengungkap-kan isi hatinya secara bebas. Memberi kesempatan orang lain berbicara merupakan perbuatan yang harus dilatihkan dan dibiasakan sejak anak usia dini. Jika kegiatan ini tidak pernah diberikan kepada anak usia dini, maka anak tersebut tidak akan terbiasa untuk mengemukakan pendapatnya, bahkan dia akan menjadi anak yang minder dan tidak percaya diri. Oleh karena itu anak usia dini mesti harus dilatihakan dan dibiasakan untuk mengemukakan pendapat dan isi hatinya, sehingga ia akan menjadi anak yang berani untuk berpendapat, meskipun pendapatnya itu salah. Anak yang tidak biasa dilatih untuk berpendapat, ia akan menjadi anak murung, kurang berani bergaul, dan tidak percaya diri. Jika hal terseut terjadi, maka anak itu akan menjadi anak yang pemurung.

Membiasakan dan membentuk pribadi yang berani mengemukakan pendapat mestinya harus dimulai sejak anak berada dalam lingkungan keluarga,tetangga, teman sebaya, dan di lingkungan sekolah. Lingkungan sekolah memiliki peran yang sangat strategis dalam usaha pembentukan pribadi positif dalam bentuk memberi kesempatan pada teman untuk berpendapat. Latihan bagi anak usia dini di TK untuk memberi kesempatan pada teman lain berpendapat selalu dilakukan di TK ABA Yogyakarta. Mereka telah dibiasakan utnuk memberi kesempatan teman lain berbicara dan mengemukakan pendapatnya secara bergantian. Meskipun latihan pembiasaan ini memerlukan keseriusan dan kesungguhan guru dan kepala sekolah untuk selalu memberi kesempatan kepada anak untuk berbicara.

Antri. Budaya antri memang merupakan budaya yang sangat bagus. 
Akan tetapi begitu sulit untuk membentuknya, dan begitu berat untuk merealisasikannya. Kita masih sering menyaksikan sebagian masyarakat yang belum terbiasa melakukan budaya antri. Misalnya tatkala membeli tiket perjalanan (pesawat, kereta, bus, kapal) masih saja sering terjadi orang menyerobot tanpa rasa risih dan malu oleh orang yang sedang antri. Dengan seenaknya tanpa malu dia nyelonong melewati antrian menuju loket penjualan tiket, meskipun orang yang antri itu secara beramai-ramai menyoraki orang yang nyelonong tersebut. Dia melenggang tanpa punya rasa salah sedikitpun. Kasus terjadi ketika orang menyerobot untuk mendapatkan jatah daging kurban di masjig Istiqlal beberapa waktu lalu, sampai terjadi banyak yang pingsan gara-gara antriannya diserobot dari belakang. Kasus semacam ini masih saja terus terjadi hingga sekarang tanpa ada rasa bersalah.

Pembiasaan antri yang ditanamkan sejak anak usia dini di berbagai taman kanak-kanak termasuk di TK ABA Yogyakarta memerlukan ketekunan para guru dan pengasuh di sekolah tersebut. Pembiasaan ini hanyalah merupakan awal dari pembentukan yang harus dilakukan secara terus menerus oleh orang tua di rumah. Guru dengan sabar dan tekun untuk mengatur dan menjaga agar anak didiknya senantiasa berprilaku antri dalam berbagai kegiatan yang memerulakn keterlibatan banyak teman dan banyak orang. Guru tetap menjadi teladan bagi anak usia dini di sekolah dan tetap membiasakan berlaku antri dalam berbagai kegiatan dan kesempatan yang melibatkan banyak orang. Misalnya antri mencuci tangan, antri mengambil peralatan belajar, antri mengembalikan peralatan bermain pada tempatnya, dan antri bersalaman dengan ibu guru.

Saling menghargai. Perbuatan yang mulia dan utama dalam berinteraksi antar sesama manusia adalah saling menghargai. Orang harus menghargai karya oyang lain dalam bentuk apapun yang dihasilkannya. Orang harus menghargai orang lain dalam bentuk perbuatan apapun yang dilakukannya selama kelakuan itu positif. Orang mesti menghargai orang lain atas jerih payahnya. Orang mesti mengakui keberadaan orang lain terhadap apa yang dimilikinya. Pengakuan dan penghargaan tersebut yang dialamatkan kepada orang lain yang telah berkarya, mestinya harus terus dipupuk dan dikembangkan sejak anak usia dini melalui berbagai kesempatan dan kegiatan nyata. Anak mesti dilatih untuk menghargai karya orang lain yang dihasilkan teman di kelasnya. Anak mesti dilatih untuk menghargai pemberian teman lain, apapun bentuk pemberiannya. Anak mesti dilatih untuk menghargai teman lain yang sedang berbicara di kelasnya, apapun yang dibicarakannya oleh teman tersebut.

Perbuatan dan prilaku saling menghargai diantara teman merupakan hal yang sangat berharga dan sangat bagus guna pembentukan akhlakul karimah. Sifat saling menghargai tidak bisa tumbuh begitu saja dengan sendirinya, melainkan harus dilatih dan dibimbing sejak anak usia dini di sekolah maupun di rumah. Di rumah anak mesti dibiasakan untuk dihargai atas segala hasil karya dan perbuatannya yang baik, dan diingatkan atas perbuatannya yang tidak baik. Anak di rumah dihargai atas ucapannya yang baik, dan dibetulkan jika ada perkataan dan ucapannya yang tidak baik. Demikian juga di sekolah anak dilatih dan dibiasakan untuk saling menghargai terhadap perkataan, ucapan, perbuatan dan karya-karya dirinya maupun karya teman-temannya.

Berbicara baik dan sopan. Persoalan yang sangat penting lainnya dalam membangun karakter anak usia dini adalah berbicara sopan. Berbicara sopan mengandung makna bahwa apa yang dibicarakan itu adalah hal-hal yang baik dan benar. Selain itu cara berbicaranyapun benar. Ungkapan-ungkapan yang dibicarakan juga bernilai benar. Serta memahami orang yang diajak bicara secara benar. Artinya anak sudah harus dipahamkan dia berbicara dengan siapa. Apakah dia berbicara dengan teman sebaya, berbicara dengan orang yang lebih tua dari dirinya, 
berbicara dengan orangtua, dan berbicara dengan gurunya. Kesemuanya itu memerlukan tata berbicara secara baik dan sopan. Cara berbicara benar mengandung makna bahwa anak usia dini sudah harus dibiasakan berbicara dengan benar, misalnya tidak berbicara keras dan berteriak. Ungkapan kata-kata yang meluncur dari lidahpun merupakan katakata yang terpuji dan mulia, apalagi kalau teman yang diajak bicara itu berusia lebih tua darinya, atau orangtua, bahkan gurunya.

Anak usia dini yang berada di TK ABA Yogyakarta sudah mulai dibangun karakternya melalui tatacara berbicara secara apik dan sopan, semua guru dan staf sekolah memanfaatkan momentum ini secara bersama-sama guna terbentuknya kebiasaan berbicara secara sopan. Anak telah dibiasakan berbicara secara baik dan sopan kepada teman sebayanya, kepada gurunya, kepada orangtuanya, kepada orang yang lebih tua usianya, dan kepada siapa saja yang ada di lingkungan sekolahnya. Pembiasaan berbicara sopan ini telah dijadikan program rutin di lingkungan TK ABA Yogyakarta guna membangun prilaku dan pribadi yang sopan dan berakhlak terpuji.

Mendengarkan orang lain berbicara. Salah satu bentuk prilaku yang mulia adalah bisa mendengarkan orang lain berbicara. Ketika seseorang sedang berbicara dalam acara formal, mestinya orang lain yang ada dalam forum tersebut berusaha sekuat tenaga untuk mendengarkan dan memperhatikan apa yang sedang dibicarakannya itu. Kebiasaan mendengarkan orang lain berbicara kini sudah surut, bahkan di banyak kasus, orang tidak lagi mendengar apa yang dikatakan orang lain itu. Orang sekarang sudah mulai emoh mendengar nasihat orang lain yang dialamatkan kepada dirinya. Jika hal seperti ini dibiarkan terus menerus tanpa ada upaya untuk memperhatikan dan mendengar kan orang lain berbicara, maka akan muncul generasi yang tidak peduli terhadap nasehat orang lain. Jika hal ini terjadi akan sangat berbahaya bagi generasi mendatang.

Oleh karena itu, orang tua di rumah dan guru pendidikan anak usia dini di sekolah harus berusaha membawa anaknya dan peserta didik membiasakan mendengarkan orang lain berbicara. Biasakan anak usia dini di sekolah mendengarkan pembicaraan temannya sendiri serta bergiliran berbicara. Biasakanlah anak mendengarkan nasehat bapak ibu guru di sekolah. Biasakanlah anak usia dini di sekolah dan di rumah mendengarkan teman membaca puisi, temannya bercerita pengalaman, bercerita piknik, dan bercerita hasil kunjungan ke tempat wisata. Anak usia dini di TK ABA Yogyakarta selalu dilatih oleh gurunya untuk mendengarkan orang lain berbicara. Menghargai orang lain berpendapat, menghargai orang lain berbicara tentang pengalamannya, dan berbicara tentang kesenang-annya. Usaha tersebut merupakan bukti nyata bahwa mendengar orang lain berbicara itu merupakan perbuatan penting dan mulia.

Prilaku modeling. Hal yang sangat penting dalam membangun karakter adalah senantiasa memberi contoh yang baik dalam segala aspek kehidupan. Contoh yang baik yang selalu ditunjukkan dan ditujukan kepada anak merupakan upaya pembentukan karakter yang sangat ampuh. Sebab, dengan contoh tidak perlu lagi mengulang dengan kata-kata. Memberi contoh kepada anak dalam menjadikan prilaku lekat dan tidak mudah luntur. Memberi contoh kepada anak sama halnya dengan membentuk pribadi yang unggul. Orangtua dan guru yang selalu member contoh akan selalu diikuti oleh anak dan sekaligus dibuat sebagai modeling bagi dirinya. Dengan contoh, anak akan menjadikan orang yang dicontoh itu sebagai cita-cita yang akan ditempuhnya dan dijadikannya contoh di kemudian hari. Dengan contoh yang diberikan anak akan mudah untuk mengikuti terhadap prilaku yang dicontohkannya itu.

Pemberian contoh yang dilakukan di TK ABA Yogyakarta baik itu yang 
dicontohkan oleh kepala sekolah maupun seluruh guru dan personil sekolah, ternyata membawa suasana belajar yang menyenangkan bagi anak TK tersebut. Mereka dengan senang hati mencontoh perkataan dan perbuatan gurunya di sekolah. Mereka mencontoh gurunya membuang sampah pada tempatnya, mereka mencontoh gurunya menempatkan sepatu pada rak sepatu, dan mereka melakukan cuci tangan dengan antri sebagaimana gurunya member contoh. Memberi contoh kepada anak merupakan langkah mendidik yang sangat agung, yang barangkali di era sekarang ini, kadangkadang contoh yang baik dan bisa diikuti itu sangatlah sulit. Oleh karenanya, selalu berikan contohlah anak-anak kita dengan perbuatan dan perkataan yang baik dan benar.

\section{Pembahasan}

Jujur merupakan suatu sikap yang sangat utama bagi setiap manusia. Pembiasaan bersikap jujur yang telah dialakukan oleh anak TK di Kota Yogyakarta berawal dari pembiasaan yang telah dilakukan oleh guru TK itu sendiri. Sebab bersikap jujur mesti harus dibiasakan sejak dini secara konsisten (Wismiarti, 2004:160). Pembiasaan yang dilakukan sejak dini dapat menumbuhkan potensi yang dimiliki anak (Rasyid, 1994; Rasyid, 1998). Kejujuran juga merupakan prilaku yang tidak bisa muncul secara tibatiba, melainkan harus dibiasakan sejak anak usia dini, sebab potensi kejujuran memang sudah ada dalam diri anak sejak mereka dilahirhan. Oleh karena itu membiasakan berlaku dan berbuat, serta berkata jujur mesti harus dibiasakan sejak dini. Sebab, dengan pembiasaan jujur yang tertanam sejak dini, akan menumbuhkan sikap yang dilakukan secara konsisten oleh anak (Megawangi, dkk, 2005:3). Pembiasaan berlaku jujur yang terus menerus akan mampu menumbuhkembangkan anak untuk melakukan latihan-latihan dasar yang dianjurkan dan dicontohkan, (Oberlander, 2005; Megawangi, dkk, 2005; Leonhardt, 1999).
Jadi perbuatan anak untuk berlaku jujur itu sesuai dengan apa yang dilihat dan dicontohkan oleh orang lain (guru dan orangtuanya), sebagai ungkapan isi hati yang telah terbiasa dilakukan secara terus menerus.

Dari perbuatan jujur akan mencerminkan ungkapan isi hati dalam bentuk perbuatan dan ucapan yang tidak menyakiti dan tidak saling menyakiti orang lain. Jika sikap-sikap tersebut telah muncul sebagai bentuk prilaku, maka akan muncul sikap saling tolong-menolong pada diri anak usia dini. Sebab pada masa usia dini ini sangat akurat untuk mulai belajar berbagai macam kehidupan (Papalia \& Olds, 1986:9). Belajar berbagai kehidupan bagi anak usia dini itu harus distimulasi melalui contoh yang dilakukan secara terus menerus. Semua hal yang dicontohkan seperti berbuat jujur, tidak menyakiti teman, tolong menolong, akan terkopi secara ajaib dalam diri anak, dan pada waktunya kelak jika diperlukan akan muncul dalam bentuk perbuatan (Papalia \& Olds, 2001:310).

Perbuatan anak usia dini itu akan terbentuk dengan baik manakala mereka telah melihat orang yang telah melakukan suatu perbuatan itu. Sebab anak usia dini itu akan meniru perbuatan orang yang dilihatnya. Crain dan Martinko menyebut sebagai proses imitasi atau peniruan tindakan (Crain, 2005:202; Martinko, 2004). Misalnya orangtua atau guru telah memberi contoh mengembalikan barang pada tempatnya anak akan meniru perbuatan tersebut dengan catatan harus senantiasa dilakukannya secara bersamasama dengan mereka. Demikian juga anak akan melakukan perbuatan seperti untuk berbicara secara bergantian, bermain bergantian, dan memberi kesempatan kepada teman untuk berpendapat, termasuk antrian dalam melakukan sesuatu adalah bagian dari meniru perbuatan orang yang dilihatnya. Meniru perbuatan orang lain merupakan bagian dari perkembangan social anak sebagai langkah awal dalam menumbuhkan harmoni sosial mereka. Harmoni sosial ini sejalan dengan pendapat 
Arthur (1998:87) yang meliputi: memberi kesempatan untuk memandang orang lain; berinteraksi dengan anak lain; menghargai elemen sosial; berbagi variasi permainan yang bersumber pada pengalaman; berbagi fasilitas dalam permainan interaksi sosial; mengembangkan otonomi dan inisiatif; menghargai perdapat anak yang lain; realistik, jujur dan seimbang; membantu anak mengembangkan diri; mengobservasi pola-pola interaksi; mendorong anak saling berunding dan negosiasi; memahami serta respek terhadap emosi anak.

Harmoni sosial yang terbentuk dalam diri anak usia dini merupakan suatu kompetensi sosial dan kesadaran sosial yang dapat memecahkan masalah sosial anak. Pembiasaan harmoni sosial yang telah dibangun pada masa anak usia dini akan membentuk kompetensi sosial anak usia dini. Kompetensi sosial ini menurut McKenzie (2004:70) merupakan set of core skills, attitudes, abilities, and feeling fungctional meaning by the contexts of culture, neighborhood, and situation. Saling menghargai, berbicara baik dan sopan, serta mendengarkan orang lain berbicara, dan prilaku modeling merupakan bentuk prilaku kehidupan harmoni social (Erikson, 1963:75). Prilaku tersebut bisa muncul akan sangat tergantung pada peran oranmg tua dan guru dalam mebrikan contoh dan stimuloasi bagi anak usia dini. Jadi harmoni sosial anak usia dini merupakan bentuk perujudan dari contoh prilaku positif yang diberikan dan distimulasi oleh guru di sekolah dan orang tua di rumah. Dengan demikian pendidikan karakter yang telah diberikan oleh guru kepada usia dini di TK mampu membangun dan menumbuhkan harmoni sosial pada diri mereka.

\section{PENUTUP}

Mengacu pada hasil penelitian dan pembahasan yang telah dipaparkan di bagian depan, berikut ini dapat disimpulkan yaitu: 1) Pelaksanaan pendidikan karakter di TK Propinsi Daerah Istimewa Yogyakarta yang meliputi kejujuran, ungkapan isi hati, tidak saling menyakiti, tolong menolong, mengembalikan barang pda tempatnya, gantian berbicara, member kesempatan orang lain berpendapat, antri, saling menghargai telah berjalan dengan baik dibawah bimbingan guru. 2) Harmoni sosial pada anak TK Propinsi Daerah Istimewa Yogyakarta telah terbangun dengan baik diantara sesama mereka melalui pergaulan akrab mereka baik di kelas maupun di luar kelas, meskipun mereka datang dari berbagai latar belakang suku dan bahasa.

\section{Saran}

Saran yang dapat disampaikan dalam kesempatan ini yang mengacu pada penelitian yang telah dilakukan adalah: 1) Sebaiknya penelitian yang akan dilakukan oleh siapa saja disarankan mengacu pada tema harmoni sosial yang dilatari oleh suku, ras, maupun golongan, dan agama guna menelusuri titik kesamaan diantara mereka. 2) Sebaiknya penelitian yang akan dilakukan di waktu mendatang merupakan lanjutan untuk mengungkap karakter mendasar anak yang dilandasi oleh perbedaan suku, ras, golongan maupun agama, sehingga akan ditemukan kesamaan dalam perbedaan sejak dini.

\section{DAFTAR PUSTAKA}

Arthur, L. et al. (1998). Programming and Planning in Early Childhood Setting. Sydney: Harcourt Brace.

Berk, E. L. (1989). Child Development. Boston: Allyin and Bacon.

Crain, W. (2005). Theory of Development: Concepts and Applications. New Jersey: Pearson Prentice Hall.

Depdiknas. (2000). Filosofi, Kebijakan dan Strategi Pendidikan Nasional. Naskah Workshop, 16 Pebruari. Yogyakarta: Hotel Santika.

Erikson, H. E. (1963). Childhood and Society. Second Edition. New York: WW. Norton \& Company.

Gray, J. (2000). Children are from Heaven: Cara Membesarkan Anak secara Positif agar Anak menjadi Kooperatif, Percaya Diri, dan 
Memahami Perasaan Orang Lain. Jakarta: Gramedia Pustaka Utama.

Havelock, G. R. (1976). Planning for Innovation Through Dissemination and Utilization of Knowledge. Michigan: Michigan Institute for Social Research.

Hill-Clark, K. Y. (2005). Families as Educators: Supporting Literacy Development. Childhood Education, Vol. 82, Iss. 1; pg. 46. http://www.proquest.umi.com/pqdw eb.

Jalal, F. (2004). Arah Kebijakan Nasional Pendidikan Anak Usia Dini (Jalur Pendidikan Nonformal). Buletin PADU, Ditjen Diklusepa, Edisi khusus, hlm:39-44.

Krathwohl, R. D. (1998). Methods of Educational and Social Science Research: An Integrated Approach. New York: An Imprint of Addison Wesley Longman, Inc.

Leonhardt, M. (1999). 99 Cara menjadikan Anak Anda Keranjingan Membaca. Bandung: Kaifa.

Madjid, N. (1995). Islam Agama Kemanusiaan. Jakarta: Yayasan Wakaf Paramadina.

McCormick, M. J \& Martinko, M. J. (2004). Indentifying Leader Social Cognitions: Integrating the Causal Reasoning Perspective into Social Cognitive Theory. Journal of Leadership \& Organizational Studies. Vol. 10 (4), p. 2-11.

McKenzie, M. (2004). Seeing the Spectrum: North American Approaches to Emotional, Social, and Moral Education. The Education Forum. Vol. 69 (1), pp. 79-90. http://dx.doi.org/10.1080/00131720 408984667.

Megawangi, R., dkk. (2005). Pendidikan yang Patut dan Menyenangkan: Penerapan Teori DAP Anak-anak Usia Dini 0 Sampai 8 Tahun. Depok: Indonesia Heritage Foundation.

Mendiknas. (2005). Kebijakan Pembangunan Pendidikan Nasional; Makalah Seminar Nasional Hasil
Penelitian tentang Evaluasi Hasil Belajar dan Pengelolaannya tanggal 14-15 Mei. Yogyakarta: Pascasarjana UNY.

Morrison S. G. (1988). Early Childhood Education Today. Melbourne: Merrill Publishing Company.

Molfese, V. J., Arlene A. M., Jennifer L. B., Jessica D. N., Shelby A. B., C. Jeffrey B., and Andrew M. (2006). Letter Knowledge, Phonological Processing, and Print Knowledge: Skill Development in Nonreading Preschool Children. Journal of Learning Disabilities. Vol. 39 (4), pp. 296-305. https://doi.org/10.1177/0022219406 0390040401

Nitko J. A., \& Brookhart M. S. (2007). Educational Assessment of Student, (Fifth edition). New Jersey: Pearson, Merill Prentice Hall.

Oberlander, R. J. (2005). Slow and Steady Get Me Ready: 260 Minggu Tahap Perkembangan Bayi s.d 5 tahun (Buku Pedoman Pengembangan Anak Dini Usia). Terjemahan: Susanti Harini Hartono. Jakarta: Duta Prima.

Papalia, E. D. \& Olds, W. S. (1986). Human Development. Third edition. New York: McGraw-Hill book Company.

Papalia, E. D. \& Olds, W. S. (2001). Human Development. Eight edition. New York: McGraw-Hill book Company.

Piaget, J. (1974). The Construction of Reality in the Child, New York: Ballantine Books.

Purba, S. Y. (2007). Aku takut ke sekolah. Kompas 19 Pebruari 2007.

Quraish, S. M. (2000). Wawasan AlQur'an. Bandung: Mizan.

Rasyid, H. (1994). Perspektif Islam tentang keberadaan anak: Suatu kajian pedagogis. Suara Almamater, No 9 Tahun X. Pontianak: Publikasi Ilmiah Universitas Tanjunagpura. 
(1998). Pendidikan dan

Pembelajaran di Lingkungan

Keluarga. Jurnal Pendidikan Islam:

Konsep dan Implementasi, Volume 4 TH. III Maret.

(2008). Asesmen Perkembangan Anak Usia Dini. Yogyakarta: Pustaka Pelajar.

Wismiarti. (2004). Pendidikan Anak Usia Dini Berbasis Kecerdasan Jamak di Sekolah Al-Falah. Buletin PADU, Ditjen Diklusepa. Edisi khusus, (3944). 